\title{
A mixed-methods examination of the geospatial and sociodemographic context of a direct-to-consumer food system innovation
}

Jared T. McGuirt ${ }^{\text {** }}$

University of North Carolina at Greensboro

\author{
Marilyn Sitaker ${ }^{b}$ \\ Evergreen State College \\ Stephanie B. Jilcott Pitts ${ }^{c}$ \\ East Carolina University
}

Alice S. Ammerman ${ }^{d}$

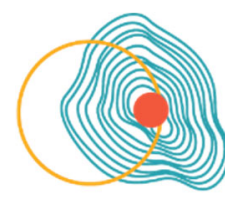

PLACE-BASED FOOD SYSTEMS CONFERENCE: Making the Case, Making it Happen August 9-10th, 2018
Jane Kolodinsky

University of Vermont

Rebecca A. Seguin-Fowler ${ }^{\mathrm{f}}$

Texas A\&M University

Submitted December 18, 2018 / Revised February 18, March 28, May 15, and June 3, 2019 /

Accepted June 4, 2019 / Published online August 23, 2019

Citation: McGuirt, J. T., Sitaker, M., Jilcott Pitts, S. B., Ammerman, A. S., Kolodinsky, J., \& Seguin-Fowler, R. A. (2019). A mixed-methods examination of the geospatial and sociodemographic context of a direct-to-consumer food system innovation. Journal of Agriculture, Food Systems, and Community Development, 9(Suppl. 1), 159-177. https://doi.org/10.5304/jafscd.2019.091.038

Copyright (C) 2019 by the Authors. Published by the Lyson Center for Civic Agriculture and Food Systems. Open access under CC-BY license.

fruit and vegetable access for low-income individuals. The purpose of this study was to examine the sociodemographic and geospatial context (distance to pickup sites, number and density of proximal food retail outlets, etc.) surrounding community supported agriculture (CSA) pickup locations in relation to low-income customer residential locations, and to synthesize this information with inter-

e Jane Kolodinsky, PhD, Director, Center for Rural Studies; Professor, Department of Community Development and Applied Economics, University of Vermont; 206 Morrill Hall; Burlington, VT 05405 USA; Jane.Kolodinsky@uvm.edu

${ }^{\text {f }}$ Rebecca A. Seguin-Fowler, PhD, Associate Professor, Department of Nutrition \& Food Science, Texas A\&M University; 373 Olsen Boulevard Cater-Mattil MS 2253; College Station, TX 77843-2253 USA; r.seguin-fowler@ag.tamu.edu

\section{Funding Disclosure}

This material is based upon work that is supported by the U.S. Department of Agriculture, National Institute of Food and Agriculture, under award number 2015-68001-23230. 
view-derived perspectives on the challenges and opportunities of the pickup location from DTC producers and customers. This in-depth study examined cost-offset community supported agriculture (CO-CSA) operations across four U.S. states (New York, North Carolina, Vermont, and Washington) and varying pickup sites $(n=23)$, with pickup operational decisions determined by farmers $(n=12)$. Physical addresses of farms, CO-CSA customers, and pickup sites were collected and geocoded. Geographic information systems (GIS) was used to examine road network distances for pickup locations across the study sites. Demographic information at the census block level (e.g., percent racial minority, percent poverty level) was obtained for all study sites. Descriptive statistics were generated for geospatial variables. In-depth interviews with farmers and focus groups with COCSA customers were conducted to understand experiences with the CO-CSA in terms of physical access of pickup sites. We found that pickup sites were an average of 6.2 miles (10 kilometers) from customers' homes, and on average, further than the supermarket $(2.9$ miles or $4.7 \mathrm{~km})$. Farmers reported their efforts to select convenient pickup locations for low-income customers, though COCSA customers expressed mixed levels of accessibility. Spatial inaccessibility and differences in sociodemographic data for customer versus pickup may explain perceived inaccessibility for some customers. These findings may help inform future approaches to plan and evaluate DTC operations targeting low-income individuals by considering geospatial context and stakeholder experiences.

\section{Keywords}

Direct to Consumer, Community Supported Agriculture, Geographic Information Systems, Spatial Context

\section{Introduction and Literature Review}

The concept that "place matters" is central to the concept of direct to consumer (DTC) retail food system models (Blake, Mellor, \& Crane, 2010; Lohr, Diamond, Dicken, \& Marquardt, 2011). In DTC interactions, producers and customers are likely influenced by environmental context. The environmental context of food systems includes physical attributes related to land quality, marketing opportunities, and structures and facilities (including buildings, road networks, and public transportation systems), as well as nonphysical attributes, such as policies and regulations, residents' demographics, habits, perceptions, and social norms (Blake, Mellor, \& Crane, 2010; Lohr, Diamond, Dicken, \& Marquardt, 2011; Park, Mishra, \& Wozniak, 2014).

All these attributes can influence distribution channels and site location for producers to sell their goods, particularly for smaller-scale farmers who may not have the resources to overcome environmental barriers to reach certain populations or locations (Cone \& Myhre, 2000; Galt, 2013; Hinrichs \& Allen, 2008). On the customer side, the environmental context may influence the accessibility to DTC operations, particularly for lowincome individuals who face additional resource barriers (Galt, 2013). Low-income individuals have cited cost, time, transportation, habit, and food preferences as potential barriers to using DTC operations for food purchasing (Leone et al., 2012; McGuirt, Pitts, Seguin, Bentley, DeMarco, \& Ammerman, 2018; McGuirt, Ward, Elliott, Bullock, \& Pitts, 2014; Racine, Smith Vaughn, \& Laditka, 2010). Hilbert, Evans-Cowley,Reece, Rogers, Ake, and Hoy (2014) found that rural lowincome populations may be particularly vulnerable to food-access issues because of transportation costs associated with pursuing a healthy diet, and that policy efforts should always consider placespecific factors given variation in costs.

Community supported agriculture (CSA) is a DTC model that may have potential to improve access to fruits and vegetables because of the flexible distribution opportunities compared to traditional brick-and-mortar stores or even farmers markets (McGuirt, Pitts, Hanson, DeMarco, Seguin, Kolodinsky, \& Ammerman, 2018; White et al., 2018). Given this, CSA programs may help increase access to food in both urban and rural food deserts (areas that lack access to affordable fruits, vegetables, whole grains, low-fat milk, and other foods) and food swamps (locations with food stores with abundant less healthy foods) that are common in low-income areas in the United States (Centers for Disease Control and Prevention, 2017; 
Rose et al., 2009; Walker, Keane, \& Burke., 2010). Since CSA offerings include mostly fruits and vegetables, the CSA model may also increase exposure to healthier foods and reduce exposure to lesshealthy items that are commonly found in stores within food deserts (Walker et al., 2010).

However, currently, most CSA members are middle to upper-income households, with few lowincome individuals (Cooley \& Lass, 1998; Hanson et al., 2017;; Russell \& Zepeda, 2008Vasquez, Sherwood, Larson, \& Story, 2017). Standard CSA models have been deemed elitist by some critics (DeLind, 1999). This is likely because few CSA programs have been designed for lower-income populations (Leone, Haynes-Maslow, \& Ammerman, 2017; Quandt, Dupuis, Fish, \& D’Agostino, 2013). This structure has led to lowincome consumers having limited access to local foods opportunities (Sbicca, 2012). While CSAs emphasize 'community' and a 'sharing' relationship, it is subject to the influences of 'marketness' (price as the dominant factor) and high 'instrumentalism' (prioritization of economic rather than social or moral goals) (Block, 1990). These influences have produced the predominant model that often makes CSAs inaccessible to people with limited means (Hinrichs, 2000). Some have called for the radical transformation of the agrifood system as part of the food justice movement to increase access to opportunities for low-income people (Gottlieb \& Joshi, 2010). Recent research indicates that modifications of the typical CSA approach may be necessary for low-income individuals, given resource constraints and that a convenient pickup location was a major factor for low-income consumer willingness to participate in CSA programs (McGuirt, Pitts, Hanson et al., 2018). Individuals in that study stated they were more likely to participate in a CSA when it was closer to their home than the supermarket, and if there were a price saving with the CSA (McGuirt, Pitts, Hanson et al., 2018). Previous research also suggested that accessibility was among several important factors that influence participation in a cost-offset CSA (COCSA) program aimed at reaching low-income individuals (White et al., 2018). This aligns with the geospatial distance decay theory or "friction of distance," where the interaction among two entities decreases as distance increases (Pun-Cheng, 2016). Thus, the further away a person lives from a CSA pickup, the less likely the person is to purchase the CSA, or once purchased, the less likely he or she is to pick it up regularly.

While pickup location may be a factor for all CSA customers, including high-income individuals, the additional resource constraints experienced by low-income individuals, including transportation problems (including funds to purchasing gas) as well as the time limitations with working multiple low-wage jobs, makes CSA participation riskier. The consideration of placement for low-income individuals is unique and important to any program geared toward reaching this population (Quandt, Dupuis, Fish, \& D’Agostino, 2013; McGuirt, Pitts, Hanson et al., 2018; McGuirt, Pitts, Seguin et al., 2018). For high-income populations, accessibility may be a challenge; for low-income individuals, it is a decisive consideration that may increase the risk of not having resources needed to accomplish other life needs (McGuirt, Pitts, Hanson et al., 2018; McGuirt, Pitts, Seguin et al., 2018).

There is a paucity of research that considers physical accessibility for producers and customers, the retail food environment context around distribution points, and the sociodemographic environment of farmers, customers, and pickup sites. The importance of studying the context of the accessibility of CSA models to low-income individuals is rooted in the idea that physical and human geographies are created and influenced by social and political processes that determine whether there is spatial justice (Feagan, 2007; Soja, 2013) —in this case, equitable access to healthy local foods. Understanding the dynamics of these different relational, operational, and environmental factors will help increase our understanding on food systems geography for low-income individuals, and how to achieve spatial justice as it relates to access to local healthy foods (Feagan, 2007). Factoring in physical and human geography may also help create a more holistic characterization of DTC markets for lowincome individuals. Typically, there has been an emphasis on the social and economic connections driving CSA participation, but these factors may be potentially inadequate in explaining and developing an interest in and privilege to CSA opportunities 
among low-income individuals (Hinrichs, 2000). Galt (2011) suggested the need for additional qualitative and quantitative data to better understand the distribution of CSAs.

The purpose of this study was to examine the sociodemographic and geospatial context (i.e., distance to pickup sites, number and density of proximal food retail outlets), surrounding community supported agriculture (CSA) pickup locations in relation to low-income customer residential locations, and to synthesize this information with interview-derived perspectives on the challenges and opportunities of the pickup location from DTC producers and customers.
We report the results of an exploratory approach that combines quantitative spatial analysis and qualitative evaluation. This mixed-methods synthesis approach is rooted in the 'political ecology' approach suggested by Shannon (2014), which emphasizes the usefulness of more in-depth approaches to understanding low-income geographic context based on experiences and social relations, rather than the typical strict geospatial approach that pathologizes low-income residents and leads to an unclear understanding of relations between areas and their residents (Shannon, 2014). Thus, we examine stakeholder feedback plus sociodemographic and geospatial contextual approach,

Figure 1. A Conceptual Model of Our Analytic Approach for Determining the Optimal Direct-to-Consumer Operation Locations for Farmers and Low-Income Customers (the Actors [Participant in a Process]; Green Squares) with Consideration of Spatial Factors (Influencers [the Environmental Context that Influences the Actors]; Blue Circles)

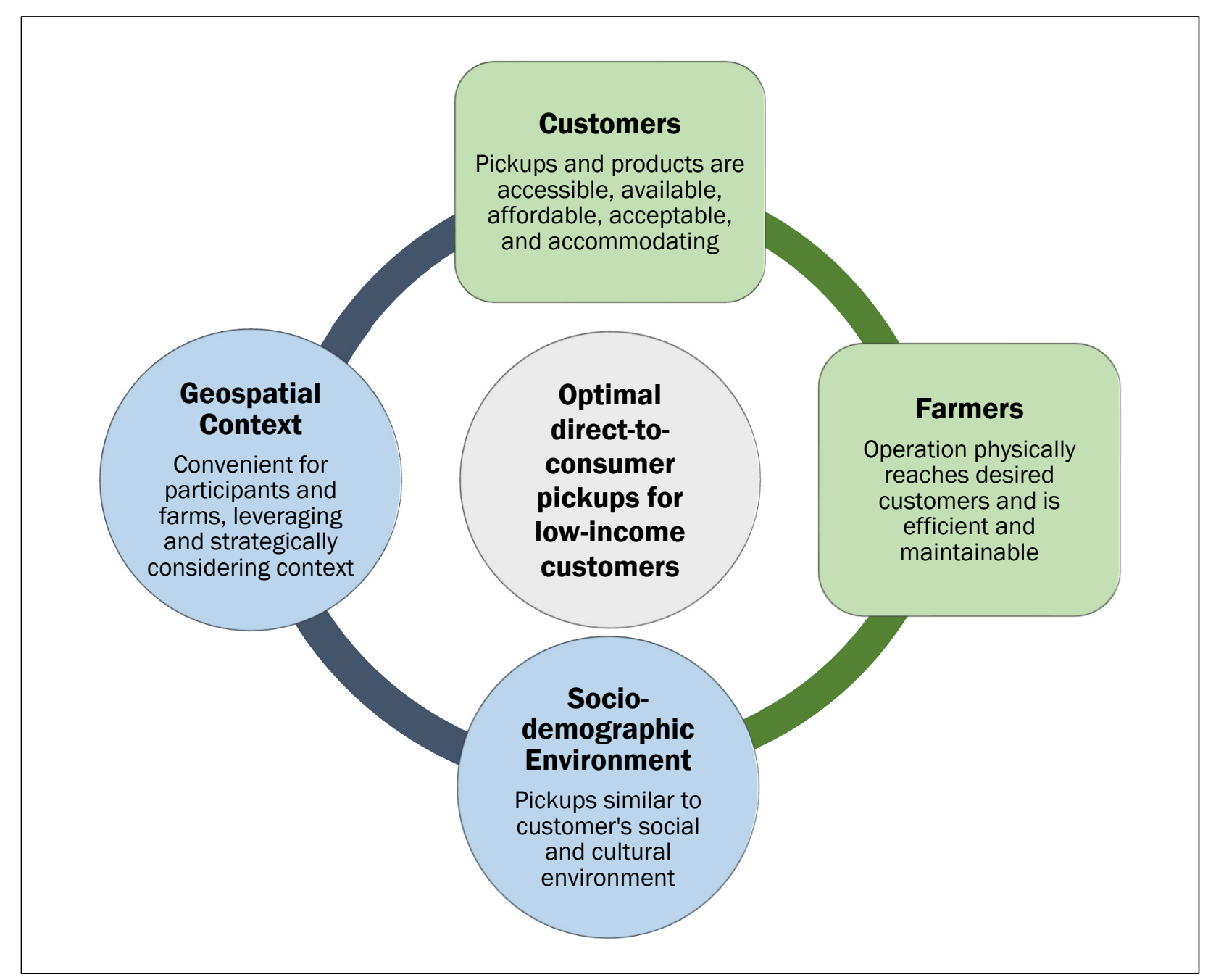


as a model to help plan and evaluate DTC operations targeting low-income individuals. Figure 1 serves as a conceptual model of our analytic approach for determining the optimal DTC operation locations for producers and low-income customers with consideration of spatial factors, illustrating the four domains we perceive as relevant to this issue based on the previously described literature. For customers, pickups and product need to be accessible, available, affordable, acceptable, and accommodating given income constraints and sociodemographic characteristics (Caspi, Sorensen, Subramanian, \& Kawachi, 2012). Farmers must make strategic, operational decisions regarding the CO-CSA, specifically the placement of pickups to meet the customers' needs as well as their own needs. The geospatial context of operation must be convenient for customers and farms, and pickup sites should be strategically selected with consideration of context (including the food store environment, which may be a facilitator allowing more efficient shopping, or a barrier if a food stores are competing against the CO-CSA). Lastly, the sociodemographic context must be considered, with pickup sites being similar to the sociodemographic context of customers. Sociodemographic differences could help explain misplaced pickups (as a proxy for being located in a different area not close to their home) and a reduced level of social and cultural connectivity, as participants may feel uncomfortable in a setting dissimilar to their typical experience. In the model, we have represented customers and farmers as formal 'actors' (participants in a process) (green squares) and the geospatial context and sociodemographic environment as contextual 'influencers' (the environmental context that influences the actors) (blue circles). The model demonstrates how the domains potentially relate and contribute to the overall goal of developing an optimal DTC operation for low-income customers. The geospatial and sociodemographic information may help triangulate findings from qualitative feedback.

\section{Applied Research Methods}

This in-depth mixed-methods cross-sectional study examined CO-CSA operations (12 farms and 16 pickup sites) across four U.S. states that were par- ticipating in the Farm Fresh Foods for Healthy Kids (F3HK) project, a U.S. Department of Agriculture (USDA) Agriculture and Food Research Initiative (AFRI) funded, randomized controlled trial that is testing a CO-CSA model in Supplemental Nutrition Assistance Program (SNAP)eligible individuals in North Carolina (NC), New York (NY), Vermont (VT), and Washington (WA) (Seguin et al., 2018). All customers were at or below $185 \%$ of the federal poverty level (as selfreported). The program consisted of a 15- to 24week summer CSA share combined with tailored nutrition education. The share price was subsidized by $50 \%$; weekly payments were allowed, and the participating farmers had to accept SNAP Electronic Benefits Transfer (EBT) as a form of payment. All F3HK participants provided their physical home address. Farms were recruited to the study by the project team based on existing CSA operations and an interest in offering a CO-CSA. Operational decisions were determined by farmers, and customer participants chose their pickup sites; thus, the research presented in this paper regarding CO-CSA pickup sites is likely representative of typical pickup site operations for CO-CSA for lowincome populations. This study examined only the intervention group customers during one year of the program as an in-depth examination of farm operations across multiple states.

Data were collected, derived, and analyzed to examine the initial suitability of the conceptual model in Figure 1. The goal was to examine whether the components of the model were influential in the success of the CO-CSA pickups for low-income customers.

The distance between pickup locations for farmers and customers, as well as the walkability (the amount and proximity of nearby amenities that can be accessed on foot) of pickup neighborhoods and those of customers, was assessed using geospatial data. We conducted all spatial analysis using ESRI ArcMap geographic information systems (GIS) (ESRI, Redlands, CA). We collected physical addresses of farms $(n=12)$, CO-CSA customers with complete home address information $(n=92)$, and CSA pickup locations $(n=16)$. Food store location (supermarkets, North American Industry Classification System (NAICS) 445110) 
data were obtained from the RefUSA business database. All address points were batch geocoded with the Google Maps application programming interface (API) through the BatchGeo website and geocoded to the highest level of accuracy possible, either to the rooftop (street address precision) or range-interpolated (interpolated between two precise points) levels.

ArcGIS and Google API were used to generate road network distance between farms and customer residences to pickup sites and to large supermarkets. Two-mile road network buffers were generated to obtain counts of supermarkets and other grocery stores near pickups and customer home address. The mRFEI data were spatially joined to customer address and pickup site locations. The U.S. census block group-level demographic information (percent minority, percent poverty level, etc.) was spatially joined to the farms, pickup sites, and customer home address data.

We used the Walk Score website (https://www.walkscore.com) (Walk Score, 2018) to generate an estimate of walkability around both customer addresses and CSA pickup sites to see if both areas were walkable (also considering the potential for walking to and from public transit stops) given the potential for transportation issues for lower-income individuals. Higher Walk Score value, which ranges from 0 to 100 , indicates increased walkability (Carr, Dunsiger, \& Marcus., 2010, 2011). Previous research has shown Walk Score to be a valid and useful measure of walkability (Duncan, Aldstadt, Whalen, Melly, \& Gortmaker, 2011; Duncan, Aldstadt, Whalen, \& Melly, 2013; Hirsch, Moore, Evenson, Rodriguez, \& Roux, 2013). The Walk Score website also provides information on proximity to public transit opportunities, which has implications for physical access to venues (Walk Score, 2018).

Accessibility to healthy food and the healthfulness of the retail food environment in both customer residential areas and pickup areas was assessed using the USDA food desert locator and the Centers for Disease Control and Prevention (CDC)'s Modified Retail Food Environment Index (mRFEI). We used the USDA Food Desert Locator to obtain polygon shapefiles designating USDA designated "food deserts," which are low-income census tracts where a significant number or share of residents is more than 1 mile or $1.6 \mathrm{~km}$ (urban) or 10 miles or $16 \mathrm{~km}$ (rural) from the nearest supermarket (USDA Economic Research Service, 2017), to determine if pickup sites were being located in food deserts to reach low-income customers with limited food access. We used the mRFEI dataset to examine the presence of healthier food stores (supermarkets, larger grocery venues, supercenters, and fruit and vegetable markets within census tracts or $1 / 2$ mile $[.80 \mathrm{~km}]$ from the census tract boundary) relative to less healthy food venues (fast food restaurants, small grocery venues, and convenience venues within census tracts or $1 / 2$ mile $[.80 \mathrm{~km}]$ from the census tract boundary) (CDC, 2018) around pickup sites and customer residences, as the relative healthiness and makeup of the food environment at either the customer residence or pickup area could influence interest in a CSA program. A higher mRFEI indicates a healthier food environment (CDC, 2018).

The sociodemographic data were used to examine how the sociodemographic context of the pickups matched that of customers, as differences could suggest misplaced pickups and a social disconnect. Demographic information was gathered from U.S. Census data (from the American Community Survey, 2012-2016, 5-year estimates) at the census block group level, and spatially joined to block group polygon spatial layers. Demographic information included(1) 'total population' (total population), (2) 'median age' (median age of the total population), (3) 'percent minority' (all nonWhite, including Hispanic), (4) 'percent poverty level' (income in the past 12 months below poverty level divided by total households), (5) 'percent car to work' and 'percent transit to work' (means of transportation to work for workers- 16 years and older divided by total workers 16 years and older, for both cars and public transit), (6) 'percent with high school degree' (high school graduate divided by Total Population 25 years and older), (7) 'median household income' (median household income in the past 12 months, inflation-adjusted), and (8) 'percent receiving SNAP' (received SNAP past 12 months divided by total population). The 'total population' variable was included to measure the potential market reach. The variables of 'percent 
minority,' 'percent poverty,' 'percent car to work,' and 'percent transit to work,' 'percent with high school degree,' 'median household income,' and 'percent receiving SNAP' were all used as potential proxies and differentiating characteristics of limited-resource populations who may have previously described resource and transportation constraints. The rationale of using these variables was to identify whether the CO-CSA pickup sites were meeting their intentions to reach customers from limited-resource populations and to see whether they were matching the sociodemographic characteristics of their customers.

Descriptive statistics, including counts, means, and proportions, were generated for all the previously described geospatial and sociodemographic variables, to compare the spatial context of pickup locations with customer home addresses. Results from customers, farms, and pickups sites were aggregated to facilitate comparison across spatial and demographic factors. One-way ANOVA was used to examine differences between farms, customers, and pickups for geospatial and sociodemographic variables. Analyses were conducted using RStudio Team (RStudio, 2016).

In-depth interviews were conducted with farmers after completion of the CSA season to understand their experiences with the season. Farmer interviews were examined to determine ways in which environmental or sociodemo- graphic context may have influenced their experiences with a CO-CSA after the first season. Farmers were asked about their overall experience with the CO-CSA, facilitators, challenges, and changes they anticipated making for the following year. Farmers were not directly prompted to discuss spatial factors.

Focus groups were conducted with CO-CSA customers after their first season of participation in the CO-CSA to better understand their experiences. Customer focus group data were examined to determine the degree and impact of physical access and environmental context on their participation. Customers were asked about their experiences, challenges, and facilitators to participation, with probes about the influence of physical accessibility.

Interviews and focus groups lasting approximately one hour were conducted by study staff using semistructured questionnaires. Audio recordings were transcribed verbatim, a detailed codebook was developed, and transcripts were coded by independent double coders using Atlas'Ti (Atlas'Ti Scientific Software Development, 2018) (for farmer data) and NVivo qualitative data analysis software (QSR International Pty Ltd., 2012) (for customer data). Relevant quotes and themes were extracted from transcripts. A word cloud generator (https://wordclouds.com) was used to display keywords that were frequently men-

Table 1. Geospatial Characteristics of Environmental Context of Farms $(n=12)$, Pickup Locations ( $n=16)$, and Customer Residential Locations ( $n=92)$

\begin{tabular}{|c|c|c|c|}
\hline Geographic Characteristic- Distance to Pickups or Farm & \multicolumn{3}{|c|}{ Results (average [avg], standard deviation [sd]) } \\
\hline Distance to pickup for customer & \multicolumn{3}{|c|}{$6.2(5.1)$} \\
\hline Distance to farm for the customer & \multicolumn{3}{|c|}{$18.4(11)$} \\
\hline Distance to closest pickup for the farmer & \multicolumn{3}{|c|}{$10.6(11.3)$} \\
\hline Distance to furthest pickup for the farmer & \multicolumn{3}{|c|}{$13.1(11)$} \\
\hline Geographic Characteristic-Environment & Farm Locations & Pickup Locations & Customer Address \\
\hline Modified-Retail Food Environment Index (avg, sd) & -- & $7.6(13.0)$ & $8.8(14.0)$ \\
\hline Food desert (\%) & -- & $13 \%(2 / 16)$ & $46 \%(42 / 92)$ \\
\hline Distance to SM (miles) (avg, sd)* & $5.3(4.0)$ & $2.4(3.1)$ & $2.9(3.1)$ \\
\hline Number of supermarkets within 2 miles (avg, sd) & -- & $2.5(2.3)$ & $1.8(2.1)$ \\
\hline Walk Score (avg, sd) & $10.0(14)$ & $40.0(25)$ & $26.3(23)$ \\
\hline Transit within 1 mile (\%) & $8 \%(1 / 13)$ & $56 \%(9 / 16)$ & $38 \%(35 / 92)$ \\
\hline
\end{tabular}

Note: 1 mile=1. 6 kilometers 
tioned in both the customer and farmer interviews (Cidell, 2010).

Finally, all domains in the conceptual model were combined to examine how each operation comprehensively aligned with the recommendations for the domains in the conceptual model and to see if the model constructs were potentially substantiated. Quotes from customers and farmers were summarized. The following variables were included for comparison with the summary of quotes: (1) customer distance to pickup, (2) farm distance to closest pickup, and (3) difference in percent of the poverty level between customer census block groups and pickup site census block groups.

\section{Results}

The results of this study are grouped according to the domains found in the conceptual model (Figure 1).

\section{Geospatial Context}

The geospatial findings are shown in Table 1. Example maps are shown in Figures 2 and 3 . The average distance from the customer's home to the pickup sites was just over 6 miles $(9.7 \mathrm{~km})$, which was twice the average distance from the customers' homes to the closest supermarket ( 2.9 miles or $4.7 \mathrm{~km})$. Farm locations were, on average, over 10 miles $(16 \mathrm{~km})$ from the closest pickup location, and over 13 miles $(21 \mathrm{~km})$ from their furthest pickup location, but there was a fair amount of variability in distance to the pickup location. Four of the 12 farms (33.3\%) had on-farm pickups. Three of the farms were greater than 20 miles 0 from their furthest pickup. Farms were on average 5.3 miles or 5.3 miles (median $=3.8$; range $=1.1-11.8 ; \mathrm{sd}=4.0$ ) from the closest supermarket, with pickup and customer residences around half that distance, which was the only variable with a significant difference across the three groups (pickup site, residential address, and farm address) $(\mathrm{F}=3.77701, p=0.02)$.
Figure 2. Map of GIS Road Network Analysis between Participant Addresses, Pickups Sites, Farmer Addresses, and Retail Food Stores at North Carolina Project Site

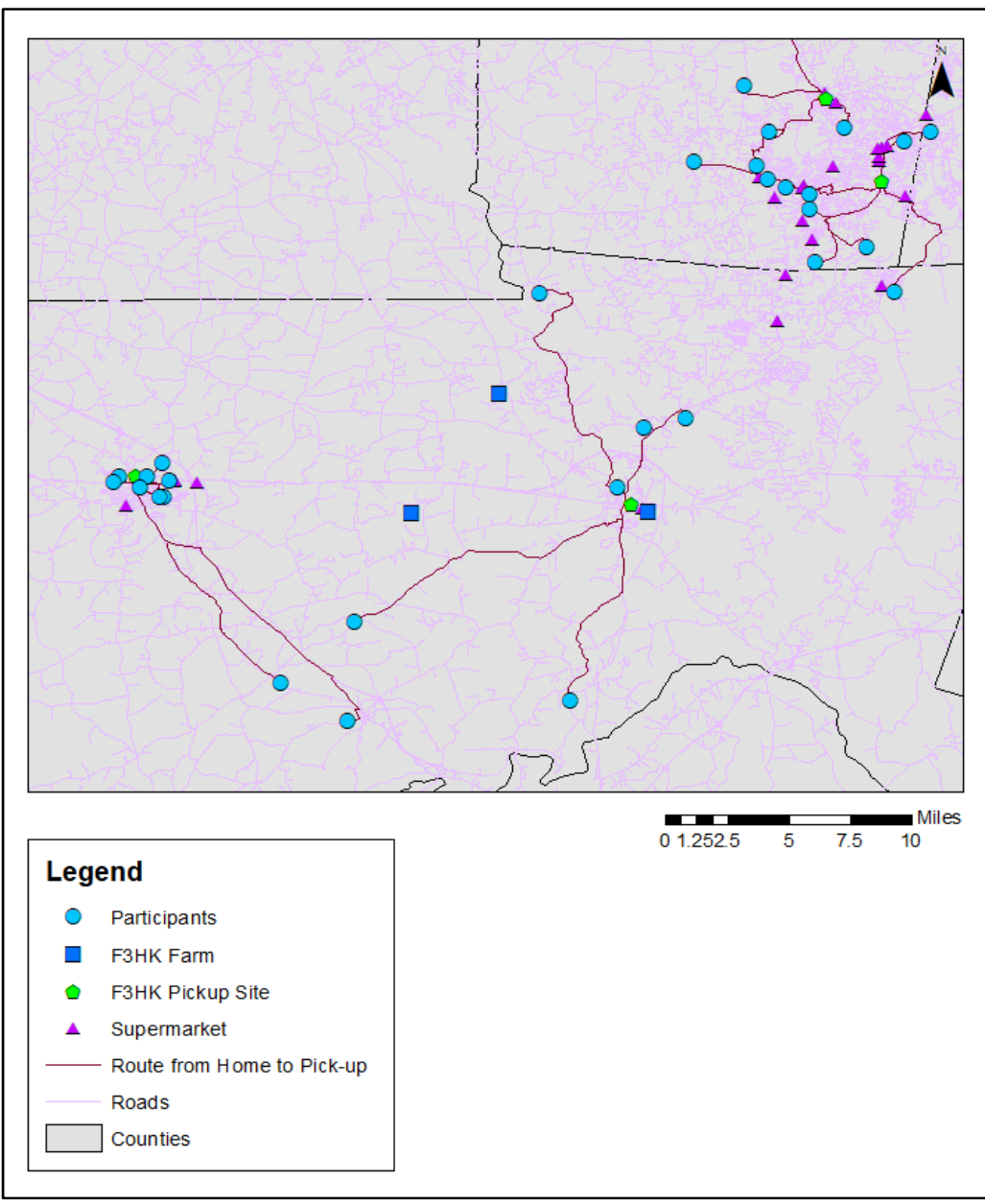

\section{Sociodemographic Context}

A summary of sociodemographic contextual findings can be found in Table 2 . The average median household income for the pickup site location (US\$48,113) was below the average U.S. median household income (\$US57,617) and the average median household income for each study state (NY: US $\$ 62,447$; NC: US $\$ 50,343$ VT: US $\$ 63,805$; WA: US $\$ 75,418$ ), but above $185 \%$ of the federal poverty level for a family of four (US\$44,995) (Guzman, 2017). Pickup sites on average were located in areas with $20 \%$ or less percent poverty, percent utilizing SNAP-EBT, and percent minority. The average age of pickup site block groups was less than 40 years old, and pickup sites were located in areas where citizens mostly 


\section{Figure 3. Map of GIS Analysis for Geospatial Characteristics of the Environmental and Sociodemographic Context of Farms, Pickup Locations, and Participant Residential Locations at North Carolina Project Site}

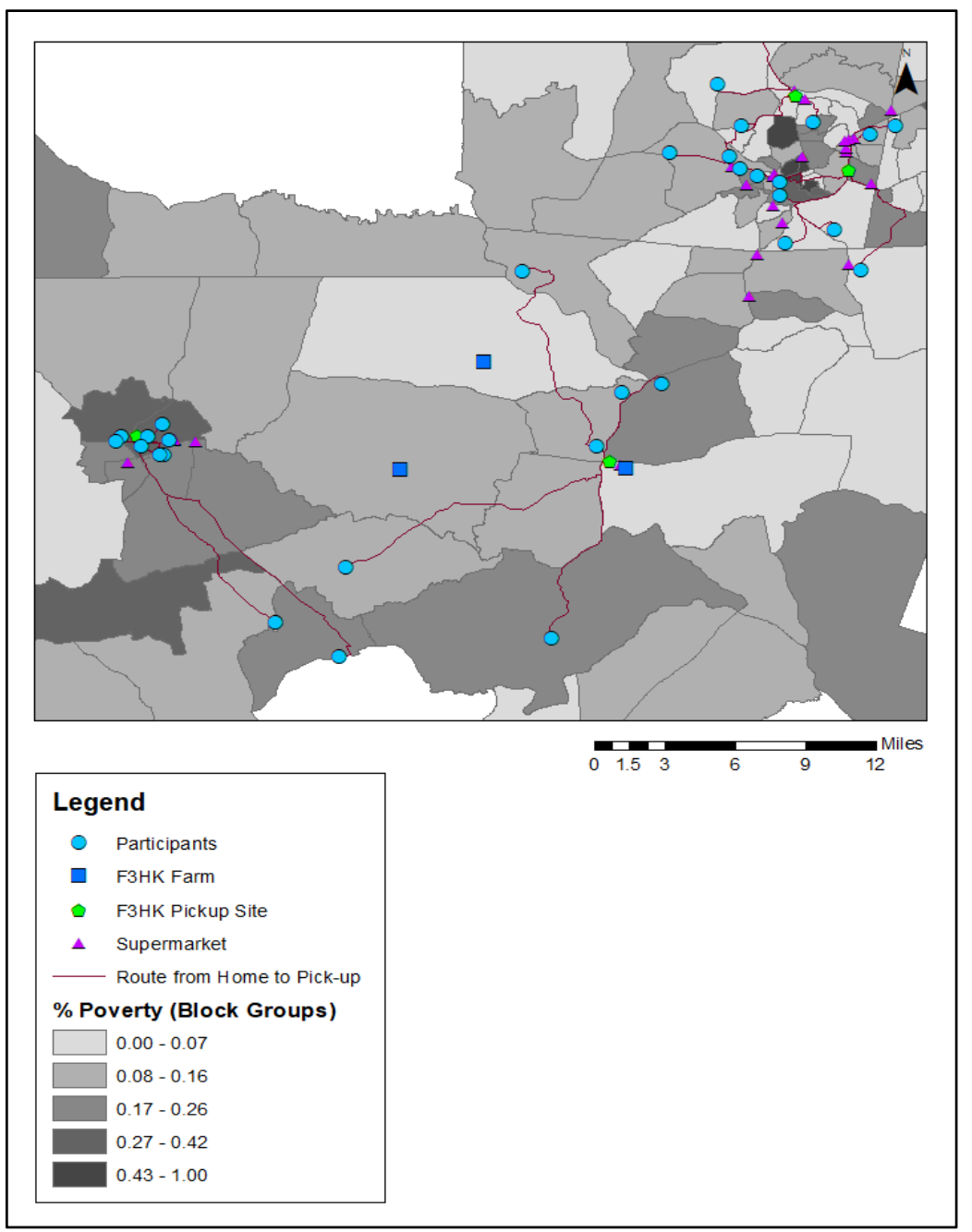

Farmer In-depth Interviews

Emerging themes from the farmer interviews included (1) realization of participant needs, (2) identification of ideal locations, (3) willingness and need to adapt the CO-CSA pickup from the typical CSA, and (4) impact on the viability of operations. Farmers identified that the CO-CSA customers often needed additional support, and when the pickup locations or time frames (related to location) may have made it conducive or challenging for some participants. Farmers mentioned strategies they took to improve customer access, including changing pickup locations or pickup times:

Farmer 2 (State 1): "I offered to switch pickup locations. Just gave them a lot more flexibility and customer support...So I think I moved fairly far away from the traditional CSA model to a more customer service subscription model."

Farmers were able to identify locations that made their operations more viable, including locating the pickup in a more central and convenient location:

Farmer 22 (State 3): “... it [was] so much easier to have central locations. It was really good. People were really happy."

Farmer 13 (State 4): "I know just walking through the regional market, the downtown market [is not great] ... There is virtually no grocery stores in that neighborhood. To be able to have a distribution point where people come with their WIC checks and EBT cards and not have to go out of their way to go to a market..."

Some farmers said they plan to offer more 
flexible options in the future to better reach and increase convenience for participants, such as moving pickup sites or offering multiple time points and locations.

Farmer 22 (State 3): "Well, we were talking about having the drop site at the [blinded] office [nonprofit offering services to low-income families]. I think that could change things and might make it more accessible to people - [with] a window of time..."

Farmer 13 (State 4): "I found for some people between work and their kids getting out of school, the time frame of that market I don't think it was most convenient for quite a few of the members. So we are looking at a couple hour farm stand [with business owners] to distribute our CSA."

For other farmers however, this amount of additional effort was troublesome for the return on investment or too burdensome to be feasible from a business operations perspective:

Farmer 43 (State 2): "So it was an issue to come pickup their food ... And my perspective is we have three different times and places ... But the way I was thinking of it was there's no other CSA in the area that's as available and flexible. I was just surprised in general the irritation with having to come get their veggies which in my head I was like, man, you've got a sweet deal, you should be psyched to come get these veggies."

Farmer 2 (State 1): "We were not going to be able to sustain the program in the future because they required a substantial amount of additional legwork and organization and flexibility that just wasn't a great fit for our farm, and potentially could be difficult for any farm ... The locations that we'd arranged were difficult."

Figure 4 provides a word cloud summary of farmer interviews. Salient words included "locations," "flexible/flexibility," "time," "difficult," and "central."

\section{Customers In-depth Interviews}

CO-CSA customers mentioned spatial factors that affected their experience in positive or negative ways. Customers reported picking up their CSA shares at a variety of locations, including at the farm, the farmers market, and at commercial locations and community buildings, and often at more convenient locations than originally planned:

PT 2 (State 1): "And it was not that bad for me because I work in [town] and I was able to pickup in [town] ... [sometimes] they actually met me, like a mile from where I work which was really super nice of her to do that, so, it's pretty convenient for me... Oh, and I picked up a couple of times too at the [town] farmers market ... Yeah, that was convenient." 
Some customers felt that site pickup locations were adequate or even increased their ability to participate. Customers said it was easier to participate when the pickups were near their home or routine daily activities, and when pickups were flexible given distance and/or time constraints:

PT 1 (State 4): "It's literally a mile from my house. It was very easy to just hop in the car, hop over there in the afternoon and then be done with it for the day. I know that's not the case for everyone."

PT 3 (State 3): "I know that it did not apply to everybody, but for me it was convenient and I am sure that if I worked at a different place or worked at different hours it would have not been convenient."

PT 1 (State 3): "It was really easy. . . I work right over by the [pickup site]. So getting here at the time that it was available was really easy."

Some customers characterized certain locations as ideal. For example, those with school-aged children appreciated having a pickup site near their child's school, and others mentioning the usefulness of a central location.

PT 2 (State 3): “It was very conveniently located for me because it was right by the school pickup. Preschool pickup on the dayso I could pick my kids up and on the way back we would go because it would be about 4:00 and we kinda made an activity of it."

Others found pickup inconvenient due to spatial factors. Several customers mentioned barriers such as distance to the pickups, traffic, placement along travel routes, parking difficulties, and time and effort (related to distance) to the pickup site given their personal time constraints. For many customers, produce pickup was "too far out" or "an extra errand" requiring more "distance traveled":

PT 7 (State 1): "I mean I think this side of town is a little far for me too because it was just out of the way after coming . . because I would pick my oldest up from practice and then come all the way over here to go all the way back home ... like it was basically a big circle around town. Gas money ... First thing that comes to mind ... or travel time ... So this place for me was not a great location either."

PT 2 (State 4): "For me our family only has one vehicle and my husband is at work until six. I make sure I'm able to get out at some point to the farm so that was kind of difficult, but we were able to work around it."

Some customers benefited from changes in pickup locations, which made it easier to get their share:

PT 5 (State 3): “After it shifted to being able to get it downtown where there was a fourhour window it was super easy and comfortable and great ... The thought of coming here [original pickup] seemed like such a hassle and so hard and stressful. After I went there I was like oh this is paradise, I love the experience. It totally shifted once that other option was given to me."

Customers mentioned several site locations that would increase accessibility to CSA pickups, including schools, homes, and central areas:

PT 2 (State 1): "Or even if they could like come to our schools you know? We have to pick our kids up at school that would be an option ... So we don't have to go out of our way. It's something we're already doing... Just make it a little more accessible."

PT 4 (State 3): "It was sometimes difficult to pick them up ... I would love to see the pickups ... if you guys could deliver our boxes to us than that would be awesome. Then I would have a box every week ... one time she left our boxes on our doorstep and that was so amazing ... I think the program 
deals with low-income people, that's my understanding, people that are really super lowincome... everything is exponentially more difficult for us."

PT 7 (State 1): "Maybe Town Hall would have been a better place to pick it up because it's like literally in the middle of town and for people who are definitely in town it's kind of not out the way. It's the center of town. It's literally near everything. Everybody probably goes to there."

Figure 5 provides a word cloud summary of customer interviews. Salient words included "convenient," "distance," "time," and "location(s)."

\section{Combined Domain Results}

Table 3 stratifies data across all four domains of the conceptual model by farm, breaking out sociodemographic and spatial data from Table 1. In combining and comparing the four data sources, we found that farmer perceptions about their distribution approach generally matched CO-CSA participant feedback. This was particularly evident regarding discussions around the flexibility of pickup locations and times and which locations were more or less successful. Many participants acknowledged and appreciated the efforts farmers made to reach them; some farmers described those efforts as worthwhile, and some described them as too challenging to retain. Farmers and participants often agreed that additional pickup opportunities were necessary to improve accessibility. Some farmers mentioned that they planned to relocate pickups to the farm; on average, that would mean greater traveling distances for pickup for customers. Not all farmers provided feedback about pickup site locations; in those cases, participants had mixed experiences, with some finding pickup locations challenging in terms of distance or spatially related attributes like proximal parking, with others having no problems with pickup locations.

Sometimes, the customers' residences were close to the pickup locations and the two locations had similar sociodemographic profiles. In other cases, pickup locations were further away and differed in sociodemographic context than the customer's residential context. Comparing the geospatial and sociodemographic data with the participant data allowed for a greater understanding of why certain customers found the pickups accessible, while others had accessibility issues. Locations that were on average further away from customers or that had site-specific characteristics (e.g., traffic, crowds) often led to perceived challenges with accessibility, and locations with larger variation in travel distances resulted in mixed levels of perceived accessibility. Differences in pickup versus customer block group percent poverty did not appear to bring out any clear differences in perceived accessibility among the customers. Though farmers often acknowledged the challenges of their pickup sites, they rarely mentioned geospatial or sociodemographic factors, and in some cases proposed pickups sites further from customers. For example, multiple farms wanted to add an on-farm pickup, which would 
Table 3. Synthesis of Customer Interviews, Farmer Interviews, and Geospatial/Sociodemographic Data

\begin{tabular}{|c|c|c|c|}
\hline Farm ID & Customer Summary & Farmer Summary & $\begin{array}{c}\text { Geospatial/Sociodem } \\
\text { ographic Variables a } \\
\text { (Yes/No) }\end{array}$ \\
\hline $\begin{array}{l}\text { Farm } 1 \\
\text { (State 1) }\end{array}$ & $\begin{array}{l}\text { Customers were evenly split about the } \\
\text { accessibility of pickup. Some described } \\
\text { distance as a "challenge," while some } \\
\text { described it as "reasonable" or } \\
\text { "convenient." }\end{array}$ & $\begin{array}{l}\text { The farmer said they offered to switch } \\
\text { pickup locations to improve customer } \\
\text { support but moved away from the } \\
\text { traditional CSA model. The farmer did not } \\
\text { think they could sustain the flexibility and } \\
\text { legwork required for this population. }\end{array}$ & No \\
\hline $\begin{array}{l}\text { Farm } 2 \\
\text { (State 1) }\end{array}$ & $\begin{array}{l}\text { Most customers felt the pickups were not } \\
\text { in the best location, mentioning distance, } \\
\text { time, and traffic as barriers. Those who } \\
\text { found it convenient lived close by or drove } \\
\text { by from work. }\end{array}$ & $\begin{array}{l}\text { The farmer mentioned that they expanded } \\
\text { hours to give people more time to get there, } \\
\text { that customers would ideally pick up at the } \\
\text { farmers market for efficiency, but they were } \\
\text { willing to add another pickup (if on the } \\
\text { farm). }\end{array}$ & Yes \\
\hline $\begin{array}{l}\text { Farm } 3 \\
\text { (State 2) }\end{array}$ & $\begin{array}{l}\text { Most customers found the pickup site at } \\
\text { the farmers market challenging due to the } \\
\text { crowds. Those who picked up at the farm } \\
\text { had a better experience. }\end{array}$ & $\begin{array}{l}\text { The farmer mentioned that they try to be } \\
\text { flexible through multiple pickup locations, } \\
\text { more than other CSAs, but that they found } \\
\text { meeting customer needs challenging. }\end{array}$ & No \\
\hline $\begin{array}{l}\text { Farm } 4 \\
\text { (State 3) }\end{array}$ & $\begin{array}{l}\text { Customer described it as convenient as it } \\
\text { was near other shopping, and farmer } \\
\text { made it easy to pick up share. }\end{array}$ & $\begin{array}{l}\text { Farmer was interested in moving the pickup } \\
\text { site to their fruit stand to make things more } \\
\text { efficient for them. }\end{array}$ & No \\
\hline $\begin{array}{l}\text { Farm } 5 \\
\text { (State 3) }\end{array}$ & $\begin{array}{l}\text { Customers were evenly split on the } \\
\text { accessibility of the pickups. Some found it } \\
\text { "convenient" and "easy," whereas others } \\
\text { said they "struggled" or found it "difficult" } \\
\text { to get there. One customer found a shift in } \\
\text { the pickup to a more accessible location } \\
\text { making it "super easy" after originally } \\
\text { finding it "hard and stressful." }\end{array}$ & $\begin{array}{l}\text { The farmer mentioned that it was so much } \\
\text { easier for them and the customers to have } \\
\text { it at central locations and was planning on } \\
\text { offering at another central location (near } \\
\text { other resources) to make it more } \\
\text { accessible. }\end{array}$ & No \\
\hline $\begin{array}{l}\text { Farm } 6 \\
\text { (State 4) }\end{array}$ & $\begin{array}{l}\text { Most customers found it convenient and } \\
\text { accessible because it was near their } \\
\text { home or work. One customer lived further } \\
\text { away and called it a "haul" and a } \\
\text { "challenge." }\end{array}$ & $\begin{array}{l}\text { The farmer stated that they positioned the } \\
\text { pickup near where their customers lived, } \\
\text { which helped make it accessible to the } \\
\text { customers. }\end{array}$ & No \\
\hline $\begin{array}{l}\text { Farm } 7 \\
\text { (State 4) }\end{array}$ & $\begin{array}{l}\text { All customers interviewed found the pick- } \\
\text { up location convenient because it was } \\
\text { near work or school. One mentioned that } \\
\text { on-farm pickup would have been nice. }\end{array}$ & $\begin{array}{l}\text { The farmer recognized that some members } \\
\text { did not find it convenient and that they } \\
\text { were considering an on-farm stand to } \\
\text { distribute the CSAs given interest. }\end{array}$ & No \\
\hline $\begin{array}{l}\text { Farm } 8 \\
\text { (State 4) }\end{array}$ & $\begin{array}{l}\text { Most customers found the on-farm pickup } \\
\text { challenging due to "distance" and "tim- } \\
\text { ing," but one liked the on-farm pickup and } \\
\text { found the pickup location "beautiful." }\end{array}$ & No relevant quotes & No \\
\hline $\begin{array}{l}\text { Farm } 9 \\
\text { (State 2) }\end{array}$ & $\begin{array}{l}\text { A customer found the location challenging } \\
\text { to get to, especially given pickup times. }\end{array}$ & No relevant quotes & No \\
\hline $\begin{array}{l}\text { Farm } 10 \\
\text { (State 2) }\end{array}$ & $\begin{array}{l}\text { The customers found the on-farm pickup } \\
\text { enjoyable but challenging since it was not } \\
\text { convenient to their homes and work, } \\
\text { citing "time" and "distance." }\end{array}$ & No relevant quotes & No \\
\hline $\begin{array}{l}\text { Farm } 11 \\
\text { (State 2) }\end{array}$ & $\begin{array}{l}\text { Customer opinion on accessibility was } \\
\text { evenly split, citing location as a problem if } \\
\text { they lived far away, or as a benefit since it } \\
\text { was close to the school. }\end{array}$ & No relevant quotes & Yes \\
\hline $\begin{array}{l}\text { Farm } 12 \\
\text { (State 3) }\end{array}$ & No quotes & No quotes & No \\
\hline
\end{tabular}

a Average customer distance to pickup $\leq 5$ miles [ $3 \mathrm{~km}$ ] AND difference in $\%$ poverty between customer and pickup block groups $\leq 20 \%$. 
have been about three times greater distance from the customers than the pickup location(s).

\section{Discussion}

This study examined the geospatial and sociodemographic context of CSA pickup locations, and the influence of accessibility on both producers' and low-income consumers' experiences and decisions. Examining geospatial and sociodemographic context, followed by synthesis with customer and farmer qualitative data, allowed for a more comprehensive understanding of the reasons why customers and farmers may have experienced challenges in participating with this type of DTC model. The mixed-methods approach used to synthesize findings across different domains may help elucidate strategies needed to optimize of DTC pickups for low-income customers, as theorized in the conceptual model (Figure 1).

Customers and farmers reported that certain locations were more accessible than others, citing spatial factors like "convenience," "distance," and "time," that impacted participation and operations. This is consistent with previous research by McGuirt, Pitts, Hanson, et al. (2018) that found pickup accessibility may be an important factor for participation in CSA programs among low-income individuals. We found that customers on average traveled further to their CSA pickup than they did to the closest supermarket. This may suggest that some customers were committed to participating despite the further distance traveled, or that the CSA was an extra shopping opportunity that complemented items obtained at the supermarket. Pole and Kumar (2015) would classify these customers as quintessential CSA members-those who would drive the extra mile to the pickup because they believe in the CSA model so much. It could also be that they really wanted and valued the fruits and vegetables offered by the CSA. The importance of pickups being convenient was mostly referred to in relation to location, but in some cases customers may also be referring to slightly different dimensions of access beyond accessibility, including availability and accommodation (Caspi et al., 2012). Thus, it may be a combination of these dimensions of access contributing to ease of pickup.

Customers mentioned the positive benefits of farm pickups, including aesthetics and experience. Research into general shopping behaviors indicates that customer satisfaction leads to increased loyalty (Suh \& Yi, 2006), and this may be particularly true for CSA participants (Hunt, Geiger-Oneto, \& Varca, 2012). In fact, the mere act of increased behavioral involvement may lead to more product satisfaction and loyalty in the CSA experience (Hunt et al., 2012). The impact of this on some low-income individuals is less clear, and financial factors may overcome this loyalty at some level. Some of our previous research indicated that lowincome consumers' willingness to participate in a hypothetical CO-CSA program was reduced when the CSA was closer to the supermarket, given their familiarity with that shopping venue and opportunity to meet all shopping needs in one place (McGuirt, Pitts, Seguin et al., 2018. Thus, future efforts should further explore and more closely consider the location of CSA pickup sites relative to other food shopping opportunities to better understand the contextual factors for low-income consumers.

Examining the geospatial and sociodemographic results showed that pickup sites were often different in context from places where customers lived, which may have influenced participation. This aligns with the previously suggested assertions that local food systems opportunities often do not align with what may be needed to encourage marginalized populations to participate (Feagan, 2007; Hinrichs, 2000; Soja, 2013). Thus, future efforts should aim to improve accessibility for customers by considering the geospatial and sociodemographic context to encourage participation in these populations.

We found that some farmers mentioned taking geographic access for limited-resource populations into account for their operations. When selecting locations, farmers may have tried to address perceived community-level need and/or tried to reach the most population-dense areas to maximize convenience and reach larger venues with more people within a smaller radius. Future research should focus on further understanding farmer-level factors for determining site location of DTC pickup locations. Multiple farmers also suggested that they had to modify their typical CSA operations for lower- 
income customers. Similarly, research by Andreatta, Rhyne, and Dery (2008) found that farmers required similar adjustments to the accessibility of operations in order to reach reaching low-income individuals with CSA programs.

This study raises important questions about how much accommodation can and should be made by farmers in terms of the number and location of CO-CSA pickup sites given the realities farmers face keeping their business operation economically viable (Galt, 2013). While reaching a new market of customers may increase sales, it also may increase the costs and time needed to distribute to the new market. Multiple farmers mentioned that they were considering moving some or all their distribution sites back to the farm to make their operations more efficient and profitable. In turn, that may increase challenges in terms of physical access to the farm's product, especially for low-resource populations, who may find traveling out to the farm more challenging given the time and costs related to personal vehicle travel and (lack of) public transportation availability in the non-urban settings where farms are often located (McGuirt, Pitts, Seguin., et al., 2018; Walker et al., 2010). Future research should specifically explore the influence of transportation access and modes, including the use of public transit, on the ability of low-income individuals to access CSA pickup sites.

Another important finding of this study is that it is possible to find synergies in pickup location and distribution strategies that work for both the producer and the consumer. Customers mentioned the convenience of sites near schools and other shopping opportunities. Additional examples may include delivering to large worksite areas, daycares, after-school programs, community centers, and churches. If pickups are in more challenging locations (e.g., heavy traffic, limited parking), providing an increased window of time to pick up shares or offering pickups on multiple days would likely improve overall accessibility. Notably, farmers who mentioned making pickup sites more accessible to consumers either saw or anticipated benefits from doing so.

While combining and comparing customer and farmer feedback with geospatial and sociodemo- graphic data may allow for more comprehensive triangulation of factors influencing customer participation and farmer operations, more work needs to be done to determine the best way to bring these data together. This novel approach comes with its own conceptual challenges and thus should be further explored, refined, and validated. This includes the need to figure out how to best interpret these differences across sites given different contexts. For example, comparing perceived accessibility with geospatial accessibility across locations can be challenging, as a distance described as "far" may be different for people across different contexts. While the impact of geospatial factors, like the road network distance to the pickup site, seems relatively clear, the use of sociodemographic data is less clear. For example, how impactful is the discrepancy in the sociodemographic context of pickup site versus customer residence? Our study did not find clear issues with perceived accessibility by differences in customer versus pickup block group percent poverty. There has been discussion that there are clear cultural differences and paradigms that have led to the exclusion of people of color from alternative food systems (Guthman, 2008), but determining the proper way to measure this impact remains unclear, particularly in the context of the accessibility of local food systems mechanisms like CSAs, which are built on social interaction and trust (Hinrichs, 2000). Thus, future research should fully investigate data across all four domains to clarify the impact of access on participation, including the use of latent variables, effect moderation, and factor analysis.

While 'location' is emphasized in this paper, it may be one of many factors in consumer decisionmaking. For example, according to Zepeda and Deal (2009), price, location, and demographics are factors that mediate the underlying relationship between values, beliefs, and norms that are the real drivers of purchase behaviors. The setting may also be important. Picking up at a location perceived to be "elitist" might result in lower participation than pickup locations that are familiar (DeLind, 1999). Thus, the sociodemographic context of distance and area is important but may be one of the multiple factors associated with customers' satisfaction and willingness to participate in CSAs. 
The limitations of this study include the small sample size, which limited analytical opportunities and generalizability. However, this study did examine CO-CSA operations across four U.S. states (NY, NC, VT, WA) with operational decisions determined by farmers, and thus may represent diverse experiences. A few of the focus groups had low participation, and participant focus group feedback may only represent those who stayed actively engaged in the program. Those who did not maintain participation in the CO-CSA program and/or did not participate in the focus group may have greater challenges with spatial factors regarding participation, and thus feedback on pickup challenges may be underrepresented. The study also fills important gaps in the field and has several notable strengths. The strengths include the mixedmethods approach integrating qualitative and quantitative data; the examination of varying aspects of the food system, including producer, consumer, and environmental context; and the use of geospatial analytics. Future research could compare location and pickup timing with other competing priorities that low-income/CO-CSA customers have (i.e., price, quality, other CSA characteristics, children's extracurricular activities, and work) to participating in CO-CSA programs. Future research should also compare low-income/CO-CSA customer priorities with priorities of higherincome/conventional CSA customers to examine for differences in priorities.

\section{Conclusions}

Our findings concerning customer and farmer per- ceptions on CO-CSA pickups in light of the surrounding sociodemographic and geospatial contexts suggest that there are multiple challenges and opportunities to making these DTC programs accessible for low-income populations. We suggest key domains that must be considered when optimizing a CO-CSA program for low-income individuals: (1) For customers: physical and financial accessibility to the CO-CSA; (2) For farmers: making CO-CSA operational decisions that increase accessibility, (3) For the geospatial context: must be convenient and consider the food store environment, and (4) For the sociodemographic environment: should be similar to the customer environment to maximize connectivity. The findings of this study and the conceptual model proposed may help inform future work related to DTC operations targeting low-income individuals by understanding the sociodemographic and geospatial environmental contexts. This field of research would benefit from a focused examination of the influence of the spatial context on this type of operation. There may be a need to test approaches to increase farmers' awareness of low-income populations' needs for accessibility, including developing an approach to help farmers better evaluate the context of the market environment for low-income customers. This might include operation optimization models that help balance consumer and producer needs. Such research could help ensure that DTC operations, such as CO-CSAs, remain economically viable and profitable, while also reducing food injustice by improving equitable access to fruits and vegetables among all populations.

\section{References}

Andreatta, S., Rhyne, M., \& Dery, N. (2008). Lessons learned from advocating CSAs for low-income and food insecure households. Southern Rural Sociology, 23(1), 116-148.

AtlasTi Scientific Software Development. (2018). Atlas Ti (Version 7.1.0). Berlin: AtlasTi Scientific Software Development GmbH.

Blake, M. K., J. Mellor, \& L. Crane (2010). Buying local food: Shopping practices, place, and consumption networks in defining food as "local." Annals of the Association of American Geographers, 100(2), 409-426. https://doi.org/10.1080/00045601003595545

Block, F. (1990). Postindustrial possibilities: A critique of economic discourse. Berkeley: University of California Press.

Carr, L. J., Dunsiger, S. I., \& Marcus, B. H. (2010). Walk Score as a global estimate of neighborhood walkability. American Journal of Preventive Medicine, 39(5), 460-463. https://doi.org/10.1016/j.amepre.2010.07.007

Carr, L. J., Dunsiger, S. I., \& Marcus, B. H. (2011). Validation of Walk Score for estimating access to walkable amenities. British Journal of Sports Medicine, 45(14), 1144-1148. https://doi.org/10.1136/bjsm.2009.069609 
Journal of Agriculture, Food Systems, and Community Development

ISSN: 2152-0801 online

https://www.foodsystemsjournal.org

Caspi, C. E., Sorensen, G., Subramanian, S. V., \& Kawachi, I. (2012). The local food environment and diet: A systematic review. Health \& Place, 18(5), 1172-1187. https://doi.org/10.1016/j.healthplace.2012.05.006

Centers for Disease Control \& Prevention. (2017). CDC Features: A look inside food deserts. Retrieved from https://www.cdc.gov/Features/FoodDeserts/

Center for Disease Control \& Prevention (2018). Census tract level state maps of the Modified Retail Food Environment Index (mRFEI). Retrieved from https://www.cdc.gov/obesity/downloads/census-tract-level-state-mapsmrfei TAG508.pdf

Cidell, J. (2010). Content clouds as exploratory qualitative data analysis. Area, 42(4), 514-523. https://doi.org/10.1111/j.1475-4762.2010.00952.x

Cone, C. \& Myhre, A. (2000). Community-supported agriculture: A sustainable alternative to industrial agriculture? Human Organization, 59, 187-197. https://doi.org/10.17730/humo.59.2.715203t206g2j153

Cooley, J. P., \& Lass, D. A. (1998). Consumer benefits from community supported agriculture membership. Review of Agricultural Economics, 20(1), 227-237. https://doi.org/10.2307/1349547

DeLind, L. B. (1999). Close encounters with a CSA: The reflections of a bruised and somewhat wiser anthropologist. Agriculture and Human V alues, 16(1), 3-9. https://doi.org/10.1023/A:1007575521309

Duncan, D. T., Aldstadt, J., Whalen, J., Melly, S. J., \& Gortmaker, S. L. (2011). Validation of Walk Score® for estimating neighborhood walkability: An analysis of four US metropolitan areas. International Journal of Environmental Research and Public Health, 8(11), 4160-4179. https://doi.org/10.3390/ijerph8114160

Duncan, D. T., Aldstadt, J., Whalen, J., \& Melly, S. J. (2013). Validation of Walk Scores and Transit Scores for estimating neighborhood walkability and transit availability: A small-area analysis. GeoJournal, 78(2), 407-416. https://doi.org/10.1007/s10708-011-9444-4

Feagan, R. (2007). The place of food: Mapping out the 'local'in local food systems. Progress in Human Geography, 31(1), 23-42. https://doi.org/10.1177/0309132507073527

Galt, R. E. (2013). The moral economy is a double-edged sword: Explaining farmers' earnings and self-exploitation in community-supported agriculture. Economic Geography, 89(4), 341-365. https://doi.org/10.1111/ecge.12015

Galt, R. E. (2011). Counting and mapping community supported agriculture (CSA) in the United States and California: Contributions from critical cartography/GIS. ACME: An International E-Journal for Critical Geographies, 10(2), 131162. https://doi.org/10.1111/ecge.12015

Gottlieb, R., \& Joshi, A. (2010). Food justice. Cambridge, MA: MIT Press.

Guthman, J. (2008). "If they only knew": Color blindness and universalism in California alternative food institutions. The Professional Geographer, 60(3), 387-397. https://doi.org/10.1080/00330120802013679

Guzman, G. (2017, September). Household income: 2016, American Community Survey briefs. Retrieved from the U.S. Department of Commerce, Economics and Statistics Division website: https://www.census.gov/content/dam/Census/library/publications/2017/acs/acsbr16-02.pdf

Hanson, K. L., Kolodinsky, J., Wang W., Morgan E. H., Pitts, S. B. J., Ammerman, A. S. . . Seguin, R. A. (2017). Adults and children in low-income households that participate in cost-offset community supported agriculture have high fruit and vegetable consumption. Nutrients, 9(7), 726. https://doi.org/10.3390/nu9070726

Hilbert, N., Evans-Cowley, J., Reece, J., Rogers, C., Ake, W., \& Hoy, C. (2014). Mapping the cost of a balanced diet, as a function of travel time and food price. Journal of Agriculture, Food Systems, and Community Development, 5(1), $105-127$. https://doi.org/10.5304/jafscd.2014.051.010

Hinrichs, C. C. (2000). Embeddedness and local food systems: Notes on two types of direct agricultural market. Journal of Rural Studies, 16(3), 295-303. https://doi.org/10.1016/S0743-0167(99)00063-7

Hinrichs, C. C., \& Allen, P. (2008). Selective patronage and social justice: Local food consumer campaigns in historical context. Journal of Agricultural and Environmental Ethics, 21, 329-352. https://doi.org/10.1007/s10806-008-9089-6

Hirsch, J. A., Moore, K. A., Evenson, K. R., Rodriguez, D. A., \& Roux, A. V. D. (2013). Walk Score ${ }^{\circledR}$ and Transit Score ${ }^{\circledR}$ and walking in the multi-ethnic study of atherosclerosis. American Journal of Preventive Medicine, 45(2), $158-166$. https://doi.org/10.1016/j.amepre.2013.03.018 
Hunt, D. M., Geiger-Oneto, S., \& Varca, P. E. (2012). Satisfaction in the context of customer co-production: A behavioral involvement perspective. Journal of Consumer Behaviour, 11(5), 347-356. https://doi.org/10.1002/cb.1370

Leone, L. A., Beth, D., Ickes, S. B., MacGuire, K., Nelson, E., Smith, R. A., . . Ammerman, A. S. (2012). Attitudes toward fruit and vegetable consumption and farmers' market usage among low-income North Carolinians. Journal of Hunger \& Environmental Nutrition, 7(1), 64-76. https://doi.org/10.1080/19320248.2012.651386

Leone, L. A., Haynes-Maslow, L., \& Ammerman, A. S. (2017). Veggie van pilot study: Impact of a mobile produce market for underserved communities on fruit and vegetable access and intake. Journal of Hunger \& Environmental Nutrition, 12(1), 89-100. https://doi.org/10.1080/19320248.2016.1175399

Lohr, L., Diamond, A., Dicken, C., \& Marquardt, D. (2011, September). Mapping competition zones for vendors and customers in U.S. farmers markets. Washington, D.C.: U.S. Department of Agriculture, Agricultural Marketing Service. https://doi.org/10.9752/MS042.09-2011

McGuirt, J. T., Ward, R., Elliott, N. M., Bullock, S. L., \& Pitts, S. B. J. (2014). Factors influencing local food procurement among women of reproductive age in rural eastern and western North Carolina, USA. Journal of Agriculture, Food Systems, and Community Development, 4(4), 143-154. https://doi.org/10.5304/jafscd.2014.044.004

McGuirt, J. T., Pitts S. B. J., Hanson K. L., DeMarco, M., Seguin, R. A., Kolodinsky, J., . . Ammerman, A. S. (2018). A modified choice experiment to examine willingness to participate in a community supported agriculture (CSA) program among low-income parents. Renewable Agriculture and Food Systems. Advance online publication. https://doi.org/10.1017/S1742170518000364

McGuirt, J. T., Pitts, S. B. J., Seguin, R. A., Bentley, M., DeMarco, M., \& Ammerman, A. S., (2018). Perspectives on a local food access and nutrition education program from Cooperative Extension nutrition educators. Journal of Agriculture, Food Systems, and Community Development, 8(3), 105-122. https://doi.org/10.5304/jafscd.2018.083.002

Park, T., Mishra, A. K., \& Wozniak, S. J. (2014). Do farm operators benefit from direct to consumer marketing strategies? Agricultural Economics, 45(2), 213-224. https://doi.org/10.1111/agec.12042

Pole, A. \& Kumar, A. (2015). Segmenting CSA members by motivation: Anything but two peas in a pod. British Food Journal, 117(5), 1488-1505. https://doi.org/10.1108/BFJ-12-2014-0405

Pun-Cheng, L. S. C. (2016, Feburary 23). Distance decay. In D. Richardson, N. Castree, M. F. Goodchild, A. Kobayashi, W. Liu, \& R. A. Marston (Eds.), International Encyclopedia of Geography: People, the Earth, Environment and Technology (pp. 1-5). https://doi.org/10.1002/9781118786352.wbieg0179

QSR International Pty. Ltd. (2012). NVivo (Version 10). Melbourne, Australia: QSR International Pty. Ltd.

Quandt, S. A., Dupuis, J., Fish, C., \& D'Agostino, R. B., Jr. (2013). Feasibility of using a community-supported agriculture program to improve fruit and vegetable inventories and consumption in an underresourced urban community. Preventing Chronic Disease, 10. https://doi.org/10.5888/pcd10.130053

Racine E. F, Smith Vaughn, A., \& Laditka, S. B. (2010). Farmers' market use among African-American women participating in the Special Supplemental Nutrition Program for Women, Infants, and Children. Journal of the American Dietetic Association, 110(3), 441-446. https://doi.org/10.1016/j.jada.2009.11.019

Rose, D., Bodor, J. N., Swalm, C. M., Rice, J. C., Farley, T. A., \& Hutchinson, P. L. (2009). Deserts in New Orleans? Illustrations of urban food access and implications for policy. Ann Arbor: University of Michigan National Poverty Center \& USDA Economic Research Service.

RStudio, Inc. (2016). RStudio Team (Version 1.1.423). Boston, MA: RStudio. Retrieved from https://www.rstudio.com

Russell, W. S., \& Zepeda, L. (2008). The adaptive consumer: Shifting attitudes, behavior change and CSA membership renewal. Renewable Agriculture and Food Systems, 23(2), 136-148. https://doi.org/10.1017/S1742170507001962

Seguin, R., Ammerman, A., Hanson, K., Kolodinsky, J., Pitts, S. J., \& Sitaker, M. (2018). Farm Fresh Foods for Healthy Kids: Innovative cost-offset community supported agriculture intervention. Journal of Nutrition Education and Behavior, 50(7), S115. https://doi.org/10.1016/j.jneb.2018.04.255

Sbicca, J., (2012). Growing food justice by planting an anti-oppression foundation: Opportunities and obstacles for a budding social movement. Agriculture and Human Values, 29(4), 455-466. https://doi.org/10.1007/s10460-012-9363-0

Shannon, J. (2014). Food deserts: Governing obesity in the neoliberal city. Progress in Human Geography, 38(2), $248-266$. https://doi.org/10.1177/0309132513484378 
Soja, E. W. (2013). Seeking spatial justice (Vol. 16). Minneapolis: University of Minnesota Press.

Suh, J. C., \& Yi, Y. (2006). When brand attitudes affect the customer satisfaction-loyalty relation: The moderating role of product involvement. Journal of Consumer Psychology, 16(2), 145-55. https://doi.org/10.1207/s15327663jcp1602 5

U.S. Department of Agriculture, Economic Research Service. (2017, May 18). Food access research atlas. Retrieved from https://www.ers.usda.gov/data-products/food-access-research-atlas/download-the-data/

Vasquez, A., Sherwood, N. E., Larson, N., \& Story, M. (2017). Community-supported agriculture as a dietary and health improvement strategy: A narrative review. Journal of the Academy of Nutrition and Dietetics, 117(1), 83-94. https://doi.org/10.1016/j.jand.2016.09.029

Walker, R. E., Keane, C. R., \& Burke, J. G. (2010). Disparities and access to healthy food in the United States: A review of food deserts literature. Health Place, 16(5), 876-884. https://doi.org/10.1016/j.healthplace.2010.04.013

Walkscore. (2018). Home. Retrieved from http://www.walkscore.com

White, M. J., Pitts, S. B. J., McGuirt, J. T., Hanson, K. L., Morgan, E. H., Kolodinsky, J., . . Seguin, R. A. (2018). The perceived influence of cost-offset community-supported agriculture on food access among low-income families. Public Health Nutrition, 21(15), 2866-2874. https:/ / doi.org/10.1017/S1368980018001751

Zepeda, L. \& Deal, D. (2009). Organic and local food consumer behaviour: Alphabet theory. International Journal of Consumer Studies, 33(6), 697-705. https://doi.org/10.1111/j.1470-6431.2009.00814.x 